\title{
Inter-Group Perceptions and Representations in Two Barcelona Neighbourhoods: Poble Sec and Sagrada Família Compared
}

\author{
Ricard Morén-Alegret, Albert Mas, and Dawid Wladyka
}

\begin{abstract}
He andado muchos caminos
He abierto muchas veredas;

He navegado en cien mares

$Y$ atracado en cien riberas $(. .$.

$Y$ en todas partes he visto

Gentes que danzan o juegan,

Cuando pueden, y laboran...
\end{abstract}

(Antonio Machado/Joan Manuel Serrat)

\section{The Deep Roots of Diversity in a Mediterranean Metropolis}

Barcelona is a coastal city that had 1,619,337 inhabitants on 1 January 2010, according to the Official Local Continuous Census (Padrón Municipal), $17.46 \%$ of whom were foreigners. Furthermore, Barcelona city is the core of a metropolitan region (RMB), which is the home to around five million inhabitants. Barcelona is also the capital of Catalonia, where Catalan and Castilian-Spanish are co-official languages. From an economic point of view, since the 1980s Barcelona has mainly been relying on services, including retail commerce, tourism, international trade and

\footnotetext{
Quote from a song written by Joan Manuel Serrat, known as 'the Poble Sec boy', based on Antonio Machado poetry. A rough translation into English is: "I have walked many ways/I have opened many paths/I have sailed one hundred seas/I have docked in many shores (...) And everywhere I have seen/People dancing or playing/When they can, and labouring...".

R. Morén-Alegret $(\triangle) \cdot A$. Mas $\bullet$ D. Wladyka

Universitat Autònoma de Barcelona, Barcelona, Spain

e-mail: ricard.moren@uab.cat; albert.mas@uab.cat; dawid.wladyka@uab.cat
} 


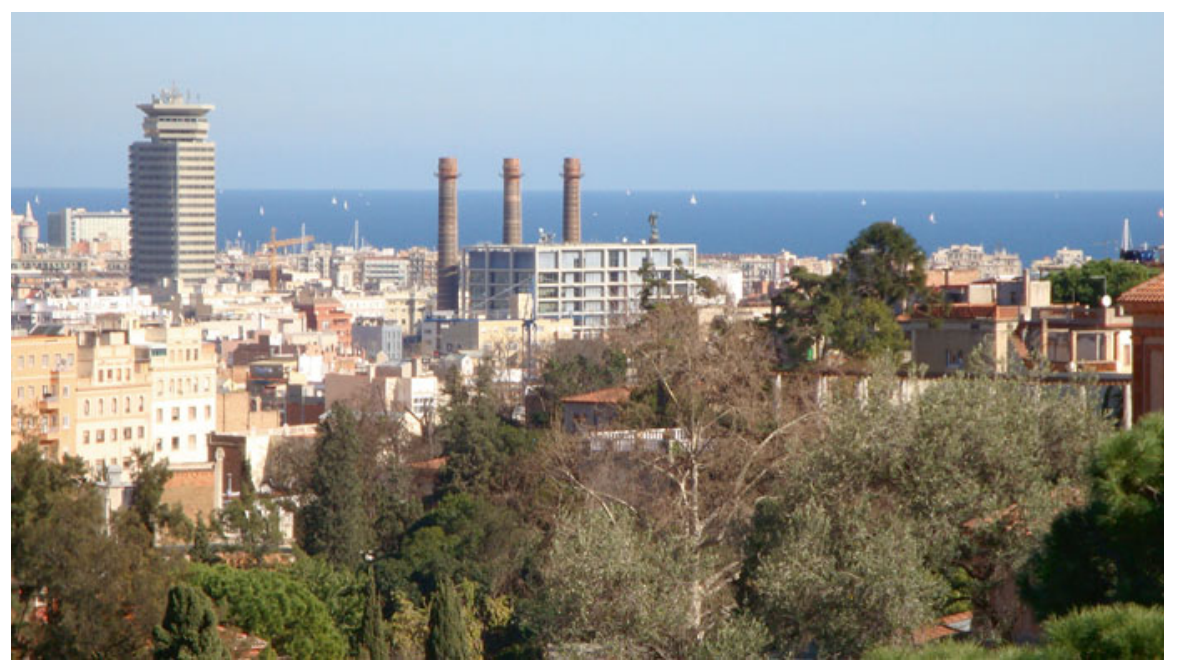

Fig. 1 Overview of densely populated Poble Sec, including the Three Chimneys' Park, and surroundings from Montjuïc Mountain (Photo by R. Morén)

construction industries that have attracted a variety of unskilled and medium-skilled immigrants. Since the 2000s, however, innovative sectors linked to cultural, educational and scientific activities, ITCs and the knowledge economy have also been attracting highly-skilled immigrants (Fig. 1).

The main focus of this chapter is on two Barcelona neighbourhoods: Sagrada Família (in the Eixample District) and Poble Sec (in the Sants-Montjuïc District). ${ }^{1}$ At the social level, both neighbourhoods have had a very active local civil society during the last decades and today they are the only neighbourhoods in their respective districts where official Community Plans ${ }^{2}$ have been implemented. As it will be explained in the following sections, the profile of both neighbourhoods constitutes an intersection of a wide variety of religions, languages, cultures and socioeconomic statuses stemming from several waves of migration. Additionally, in Catalonia, as noted above, the native population is also linguistically and culturally diverse. In order to understand how all those groups are living together (or not), one needs to gather various experiences and opinions among multiple actors who are living or working in the studied areas. In particular, as noted in the Introduction to this book, this chapter takes the super-diversity paradigm perspective into account.

This paradigm emerged from the studies of Steven Vertovec (2007) on the complex social structure in today's United Kingdom (and later in other countries). The super-

\footnotetext{
${ }^{1}$ Our fieldwork was mainly carried out from April 2011 to April 2012.

${ }^{2}$ The Community Plan (Pla Comunitari) is a mostly public-funded, neighbourhood-based, bottomup umbrella organization. The plan's goals are to diagnose the neighbourhood's basic needs and to address its most serious problems. Members of various organizations meet up on a regular basis to coordinate their organizations in order to improve their neighbourhood together (see: http://placomunitari.barrisagradafamilia.org/, and http://pcpoble-sec.org/).
} 
diversity paradigm has helped not only to capture a wider variety of immigration waves than before, but also to highlight that, within all immigrant groups (as well as native groups), there is a mosaic of individuals characterized by distinct gender, socioeconomic statuses, experiences, patterns, motives for migration, etc. A growing number of studies insist on the need to take super-diversity more into account, especially in local policymaking (e.g. Ram et al. 2013; Blommaert and Rampton 2011).

However, analyzing reality while putting a value on diversity and processes of diversification was not always a primary perspective for neighbourhood studies. As highlighted in the introductory chapter, for years researchers often linked neighbourhood studies to segregation studies. Nevertheless, as time went by, neighbourhood diversity became the central focus of research ${ }^{3}$ increasingly often.

This sub-municipal level is particularly relevant in Barcelona, where neighbourhood associations have a long history (e.g. in the 1960s and 1970s these associations channelled Spanish internal immigrants' participation) and where already in the mid-1990s the Barcelona federation of neighbourhood associations, FAVB, intended "to increase the incorporation of foreign immigrants in neighbourhood associations and in the neighbourhoods as a whole" (Morén-Alegret 2002b: 169). Since 2000, FAVB has been implementing a socio-educational program named 'neighbourhood, space for living together' (Barri Espai de Convivència BEC ${ }^{4}$ ).

In any case, however, even though both Sagrada Família and Poble Sec belong to Barcelona city and share some commonalities, in this chapter we shall show that these two neighbourhoods are quite different with regard to their urban fabric, social dynamics, economic activities and immigration flows. As noted in the Introduction to this book, these neighbourhoods belong to two broad different groups: the first and larger group is made up of former industrial areas while the second consists of relatively central neighbourhoods where the service sector (trade, leisure, museums and tourist destinations, etc.) prevails.

In toponymic and historical terms, the Sagrada Família neighbourhood was named after the homonymous Catholic church that has been under construction there since the late nineteenth century following architect Antoni Gaudí's designs. In the Catalan and Castilian languages, the toponym 'Sagrada Família' means 'Holy Family', and construction started in 1881 in former crop fields belonging to El Poblet ('little village' in Catalan), a small semi-rural setting within the boundaries of the former municipality of Sant Martí de Provençals. Those and other building activities started to attract internal rural immigrants (Ligüerre 2007). In 1897, the sparsely populated municipality of Sant Martí was absorbed by Barcelona. Historically, Poble Sec shares with Sagrada Família the fact that in the early nineteenth century it also

\footnotetext{
${ }^{3}$ In the European context, see for instance the EU-funded GEITONIES project (Fonseca and McGarrigle 2012).

${ }^{4}$ The BEC programme was initially mainly devoted to tackle the arrival of foreign immigrants to Barcelona neighbourhoods, but later the focus has widened to tackle any issue that neighbours consider as a challenge to overcome. BEC has two main aims: to carry out a participative diagnosis of the neighbourhood and to foster debates among neighbours. BEC was implemented in Sagrada Familia during 2002-2003 and in Poble Sec in 2008. See: http://barriespaideconvivencia.wordpress.com.
} 
had pockets of semi-rural activity. In the Catalan language, the toponym 'Poble Sec' means 'Dry Village'. In the past, this was an agricultural area supplying fresh vegetables to Barcelona, and it is ironic that an area that was rich in water until the early nineteenth century is known today as a dry area. From 1830 onwards, several textile industries were set up nearby, due to its proximity to the seaport, and in just 20 years the subterranean water sources were exhausted. Most of the Poble Sec neighbourhood had been protected from urban expansion because it was a military area linked to the castle located at the top of Montjuïc Mountain, but the ban on construction was lifted in the mid-nineteenth century, paving the way to housing construction, urbanization and immigration (Badenas 2006). Regarding historical ethnic-religious diversity and connections between the Poble Sec and Sagrada Família neighbourhoods, it is interesting to note that, according to several historians, the term 'Montjuïc' means 'Jewish Mountain', a toponym coined due to the Jewish cemetery located there during the Middle Ages (others, however, believe that the toponym 'Montjuïc' comes from another religious connection, from the Latin Mons Iovis, i.e., Jupiter Mountain). As another curious connection, it may be mentioned that the Sagrada Família temple, just like many other high-profile historical buildings in Barcelona, was originally built using stones from the Montjuïc Mountain quarry.

In the analysis that has been carried out during the past years, we have taken into account both differences and common factors affecting Sagrada Família, Poble Sec and Barcelona as a whole. In previous studies, the working classes have been associated with the concept of 'community' and place attachment, while in contrast the middle classes have been considered to be more individualistic and relatively less place-attached (see Halfacree and Boyle 1993). One may wonder whether a similar pattern is also emerging in Barcelona's neighbourhoods, and whether the local associative networks and institutions are relevant for immigrants' integration and, if so, how (Bruquetas et al. 2011). In this sense, it may be helpful to consider how the passage of time has affected immigrants' participation in associations (LaytonHenry 1990; Morén-Alegret 2002a, b). But before providing more information about the focus neighbourhoods, some methodological notes might be helpful in order to grasp the research project upon which this chapter is based. In the following sections, the Poble Sec and Sagrada Família neighbourhoods will be approached as contexts of social interaction (Sect. 2), the main inter-group representations occurring there will be analyzed (Sect. 3), the two neighbourhoods will be studied as objects of media representation (Sect. 4) and, finally, some further reflections on these Barcelona neighbourhoods will be offered (Sect. 5).

\subsection{Methodological Considerations}

The research project that has yielded this chapter started with documental and statistical work in order to learn from previous research and available databases on international immigration in Barcelona. It then set up a general framework and selected two sub-municipal units which were then studied in depth. Regarding the sub-municipal units of analysis considered in this research project, the selection 


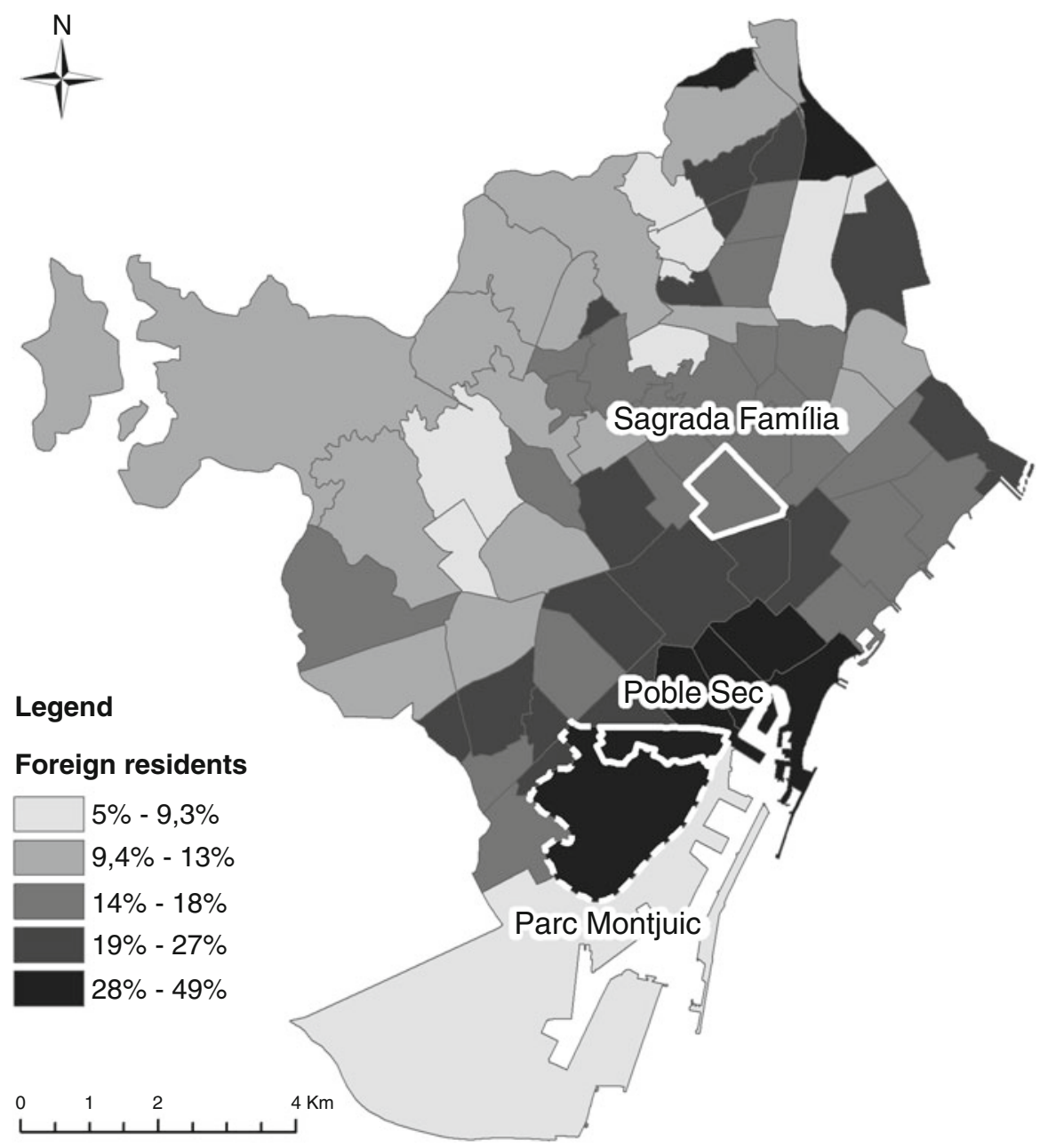

Fig. 2 Foreign registered residents in the neighbourhoods of Barcelona municipality, 1 January 2012 (Elaborated by D. Wladyka. Georeferenced data provided by ICC and IGN. Population data source: INE, 2012)

process took into account the official administrative subdivisions of the Barcelona urban area. In Barcelona there are 10 districts, subdivided into 73 neighbourhoods that are officially recognized as geographical and administrative units (see www. bcn.cat/estadistica/angles/terri/index.htm) (Fig. 2).

Our fieldwork was mainly carried out from April 2011 to April 2012. The first stage was mainly devoted to preliminary explorations and interviews with key informants and stakeholders in order to prepare a background report (available at www. concordiadiscors.eu). The second stage of the fieldwork included ethnographic activities at three 'interaction sites' in each neighbourhood (see Barcelona Final 
Report, also available on the project's website) and the organization of 'neighbourhood forums' (for more details, see the Introduction to this book by Pastore and Ponzo). An exploratory study on the local elections that took place in May 2011 was also carried out in the spring and summer of 2011, with additional interviews with representatives of the five main political parties and coalitions being carried out in both neighbourhoods (see Morén-Alegret et al. 2011).

\section{The Urban and Social Context of Social Interaction in Words and Numbers}

Poble Sec can be defined as a semi-peripheral working-class neighbourhood, with a percentage of foreign residents clearly above the Barcelona average. Sagrada Família, instead, is a semi-central lower-middle class neighbourhood, with a percentage of foreign residents around the Barcelona average (Fig. 3).

\subsection{Narrow Streets Promoting Interactions versus Busy Wide Arteries Separating Crowds}

Poble Sec has four very clearly defined boundaries: Espanya Square-Lleida Street, Montjuïc Mountain, the main seaport and Parallel Avenue. In fact, this is one of its key geographical characteristics, together with its peripheral status within the SantsMontjuïc district, the largest district in Barcelona. In contrast, Sagrada Família is part of the Eixample district, a vast city enlargement built on Barcelona plain when the walls of the old city were demolished in the nineteenth century. The boundaries of

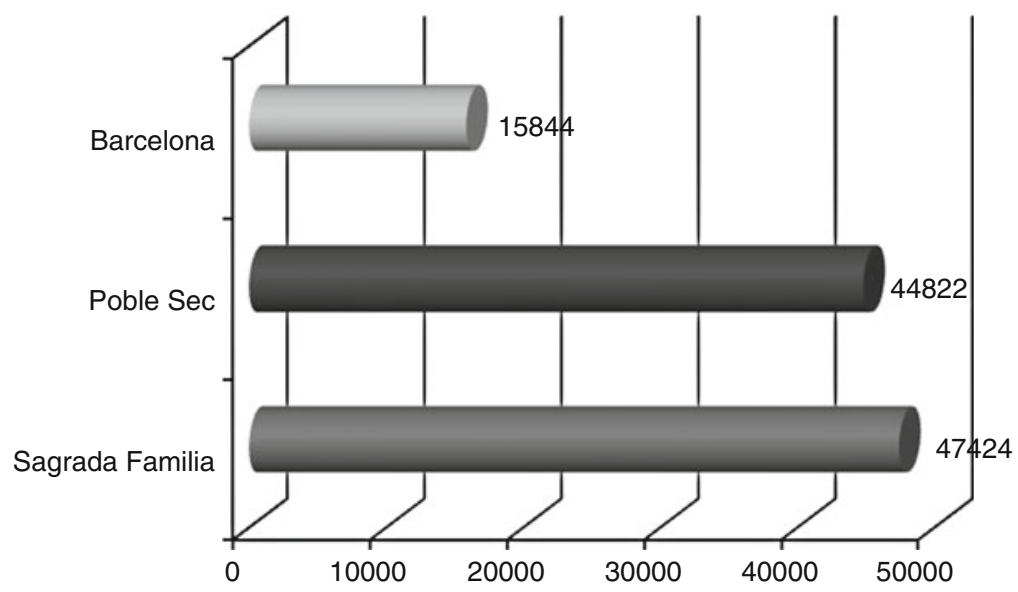

Fig. 3 Population density (population/km2) in Sagrada Família, Poble Sec and Barcelona as a whole (01.01.2010) (Continuous Census. Departament d'Estadística. Ajuntament de Barcelona) 
the neighbourhood are relatively well-known, although slightly varying depending on whom you ask, but they are easily crossed. In this sense, in Sagrada Família, the inflow of people from outside the neighbourhood is massive and particularly noticeable in the area of the Sagrada Família temple: tourist inflows and car traffic are underscored by many informants. On the other hand, in Poble Sec, there are generally few visits from people from outside the neighbourhood. It is perceived by some as a cul-de-sac because it is connected to the rest of the Sants-Montjuïc district by just a narrow corridor near Espanya Square - Lleida Street and by Montjuïc Mountain. The main routes to Montjuïc Mountain do not cross the heart of the neighbourhood:

Another characteristic that I would say about the neighbourhood is that it is a not very permeable. I mean, luckily not a lot of people come here. And I see that positively. (B-PSKI-3-Poble Sec, association member, 28 years old)

However, during recent years there has been a process of ongoing change in a few streets that are becoming part of the city's 'bohemian' leisure and nightlife scene. In contrast, in Sagrada Família there are just a few nightlife establishments and a handful of activities for young people.

Sagrada Família and Poble Sec are both densely populated neighbourhoods compared to Barcelona as a whole, but while the former is an area of transit with wide streets and a lot of car traffic, the latter has narrow streets and very little car traffic, with the exception of Parallel Avenue, one of the borders of the neighbourhood.

Sagrada Família lacks open and green spaces, especially for celebrating local festivities and for social activities in general. On the other hand, Poble Sec also has the same dearth of open and green spaces within the neighbourhood, but it borders the Montjuiic Mountain Park at one end and Tres Xemeneies Park at another. One similarity between the two neighbourhoods is a widespread perception of a lack of public services, particularly with regard to spaces and resources for children, youngsters and elderly people. Some basic services are not available within the neighbourhood, especially in the case of Poble Sec: for example, there is no adult school, and the health centre and the library are too small for the needs of the neighbourhood. In Sagrada Família, there are complaints and requests to improve short distance transport with a neighbourhood bus ('bus de barri') in order to increase accessibility for elderly people. Interviewees also mentioned the lack of a civic centre devoted solely to youth activities.

Regarding housing stocks, Sagrada Família is mostly made up of tenements of up to six floors, which house generally good quality apartments, some of which are divided into smaller flats. They were built in different periods, mainly from the urbanization of the neighbourhood in the late nineteenth century and early twentieth century to the 1970s and 1980s. Some parts of the neighbourhood, especially the squares' inner areas, were remodelled during the last decade by creating new gardens with the Pla de Barris (i.e. the Neighbourhood Plan implemented by previous centre-left Catalan governments, 2003-2010). On the other hand, Poble Sec is made up of a mixture of different kinds of housing stock. In the northern part, which touches Parallel Avenue, there are big blocks of medium-quality flats built during 1970s and 1980s. The central part contains little blocks of flats built during different periods and of varying quality, dating from the late nineteenth century and the first half of the twentieth century, but generally older than in the northern sector. On the 
other hand, in the most southern part, on the side of Montjuïc Mountain, one can find more expensive flats and houses with gardens built during the early twentieth century. Some parts of the neighbourhood have been remodelled during the last decade as part of the Neighbourhood Plan.

With regard to the local economy, while in Sagrada Família most shops and bars in the area surrounding the cathedral - the most important touristic spot in Barcelona according to number of visitors - are devoted to mass tourism, in Poble Sec tourism is generally not very relevant (except in Montjuïc Mountain). It must be added that in recent years, the economic crisis has led to the closure of several commercial establishments in both neighbourhoods.

\subsection{A Neighbourhood with Soul' versus an Impersonal Dormitory Area with a Big Cathedral}

Both neighbourhoods are very densely populated areas, clearly above the 2010 Barcelona average of about 16,000 inhabitants $/ \mathrm{km}^{2},{ }^{5}$ but from a social point of view they display very different characteristics (Fig. 4).
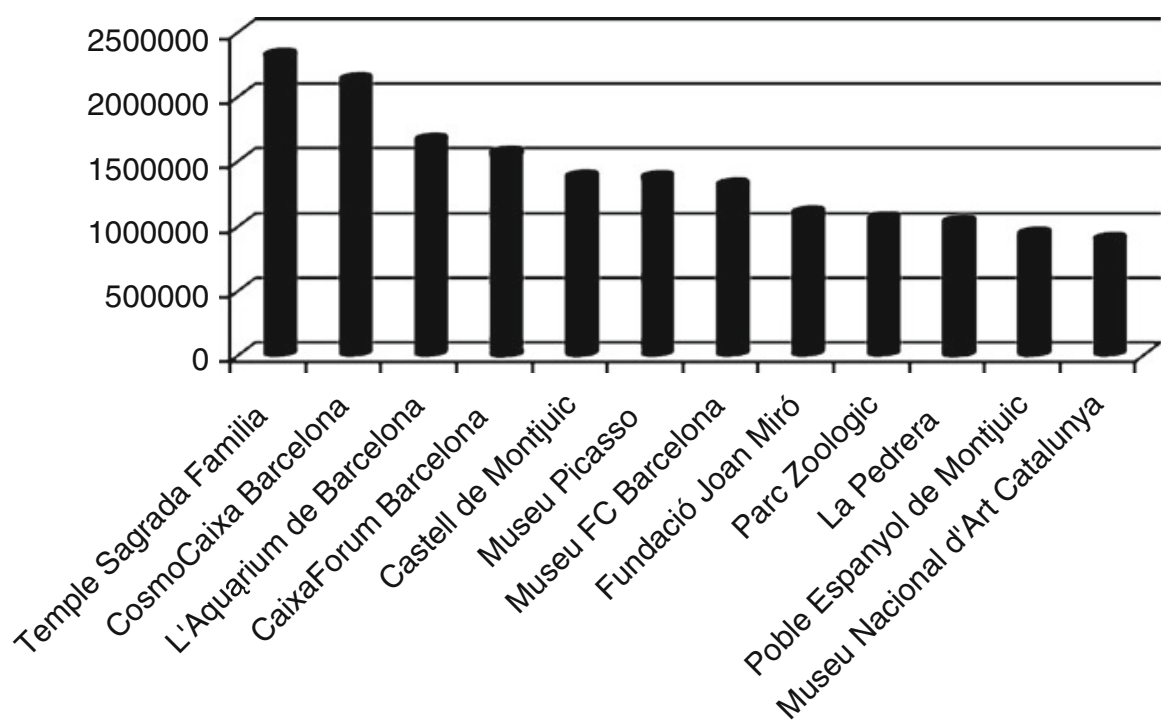

Fig. 4 The most important touristic spots in Barcelona by number of visitors in 2010, with Sagrada Familia Temple as the top of the pops (Source: Elaborated by GRM, based on data from Departament d'Estadística. Ajuntament de Barcelona. Institut Cultura Barcelona. Turisme de Barcelona)

\footnotetext{
${ }^{5}$ Sagrada Família has a population of about 52,000 inhabitants, a density of approx. 47,000 inhabitants $/ \mathrm{km}^{2}$, and $16.9 \%$ of the population was foreign (2010). On the other hand, Poble Sec has a population of about 40,000 inhabitants, a density of approx. 43,000 inhabitants $/ \mathrm{km}^{2}$, and $27.9 \%$ of the population was foreign (2010).
} 
Table 1 Percentage of foreign and national population, 01.01.2010 (INE database, municipal census official figures [elaborated by GRM] (retrieved: 24.02.2011)

\begin{tabular}{l|l|l|l|l|l}
\hline & $\begin{array}{l}\text { Sagrada } \\
\text { Família }(\%)\end{array}$ & $\begin{array}{l}\text { Eixample } \\
\text { district }(\%)\end{array}$ & $\begin{array}{l}\text { Poble } \\
\text { Sec }(\%)\end{array}$ & $\begin{array}{l}\text { Sants-Montjuïc } \\
\text { district }(\%)\end{array}$ & $\begin{array}{l}\text { Barcelona } \\
(\%)\end{array}$ \\
\hline Spanish & 83.14 & 81.96 & 72.1 & 80.26 & 82.54 \\
\hline Total foreigners & 16.86 & 18.04 & 27.9 & 19.74 & 17.46 \\
\hline $\begin{array}{l}\text { Non-EU } \\
\text { foreigners }\end{array}$ & 11.86 & 11.71 & 21.77 & 15.61 & 12.83 \\
\hline
\end{tabular}

Source: INE database, municipal census official figures [elaborated by GRM] (retrieved: 24.02.2011)

Both neighbourhoods, however, have been steadily changing with the influx of young Spanish families from other parts of Barcelona and foreign immigrants from abroad, though with some substantial differences. Sagrada Família can be considered mainly as a middle-class neighbourhood, with relatively high real estate prices that inhibit the arrival of young families and immigrant residents. In contrast, Poble Sec is a predominantly working-class neighbourhood with lower real estate prices. During the last decade, however, it has attracted growing numbers of young middleclass residents who have contributed to a more mixed social environment.

According to data from the Local Continuous Census for 2010, in both Poble Sec and Sagrada Família, the proportion of the elderly population is high, but to different degrees: in Sagrada Família, the population over the age of 64 accounts for over $22.0 \%$ of the total, while in Poble Sec it represents just $18.5 \%$. Both neighbourhoods, however, have been steadily changing with the inflow of young Spanish families from other parts of Barcelona and foreign immigrants from abroad (Table 1).

Although in both neighbourhoods there are many associations, the quality and intensity of participation in local social life can be identified as one of the main differences between the two neighbourhoods. Sagrada Família has many associations, but only a few neighbours participate in their activities: most of the residents participate little in the local social life. Many of them only sleep in the neighbourhood and spend their spare time and working hours outside of it. The neighbourhood has lost its historical identity because of its residential nature and the lack of social participation. This can be identified as one of the main differences between the two neighbourhoods.

In Poble Sec, however, there is a vivid social life: the participation in associative activities is very well-developed and involves a wide range of people and activities. It is often described as a 'friendly' neighbourhood (barrio familiar). The sense of closeness among its inhabitants is strong, and most informants interviewed during the fieldwork reported the feeling that, although the arrival of new population groups has affected the former 'chummy' social relations in the neighbourhood, there is still a balance that has allowed Poble Sec to maintain warm social relations and some degree of distinct place identity compared to other parts of the city. In the words of a young resident: 
This is a neighbourhood where there is a lot of local life, warm social relations ['caliu de barri']. Everybody knows each other, residents, shopkeepers... There is a tight social feeling among its inhabitants. And, even with the recent arrival of many newcomers - foreigners and people from other parts of Barcelona - there is still a balance with the people who have been residing in Poble Sec all their lives. (B-PS-KI-3-Poble Sec, association member, 28 years old)

However, a few informants suggested that the neighbourhood's identity is disappearing due, among other factors, to the inflow of immigrants:

It was a very united neighbourhood and with very good relationships (...), but precisely during these last ten years, when all these people from the outside have come, 'the newcomers' we call them, this has disappeared. There is no warm coexistence. (B-PS-KI-2-Poble Sec, residents' association, 58 years old)

Despite these negative opinions, in Poble Sec there are many dynamic associations to promote intercultural harmony. As clearly emerging from the gallery of cases studied in this book, social cohesion and strong neighbourhood identity play an ambiguous role since they can foster both openness and closure to outsiders. This is another difference with Sagrada Família, where there are many associations, but only a few participants in their activities. In contrast, community participation in Poble Sec is very well-developed and involves a wide range of people and activities.

\subsection{Visible and Invisible Immigrants}

In both cases, internal migration was already sizeable in the nineteenth century, when Sagrada Família, which was then called 'El Poblet', was already home to mainly rural immigrants attracted by manufacturing jobs that were better paid and more stable than agricultural work. In addition to immigrants from Catalan mountains and plains, workers also came from other regions of Spain such as Valencia, Andalusia, Aragon, Murcia and Galicia. Although the pressure of residential housing triggered the disappearance of many manufacturing businesses, several factories were still active as late as the 1960s and 1970s. During this time, there were immigrants from other parts of Catalonia and Spain in the neighbourhood, as well as from Valencia, Murcia, the Balearic Islands, Andalusia, Castile, Extremadura, Aragon, the Canary Islands and North Africa (Spaniards), as well as a few foreigners (Ligüerre 2007). Recent decades have witnessed the arrival of foreign immigrants from a wider variety of nationalities, mainly Europeans, Latin Americans and, lately, Asians.

On the other hand, Poble Sec has welcomed people from all of the different migratory waves that have settled in Barcelona during the past century. In addition to the internal rural-urban Catalan migration movements to the Barcelona metropolitan region during the twentieth century there were two major periods of growth due to internal migration: from 1916 to 1930 industrial expansion and public works required workers, who arrived principally from geographically close areas within Spain; from the 1950s to mid-1970s, the massive immigration into the Barcelona 


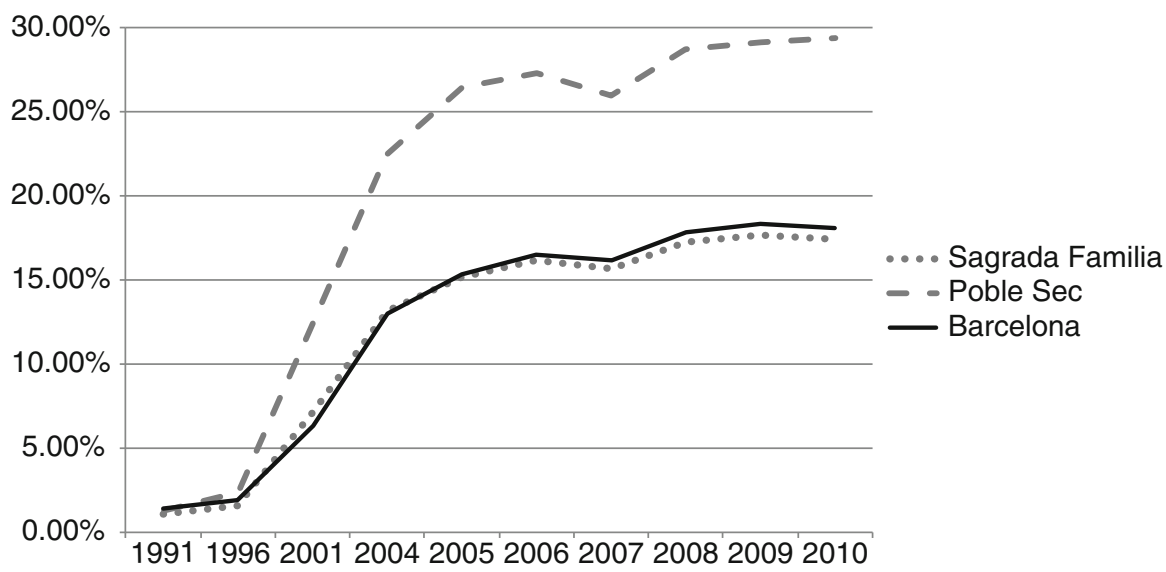

Fig. 5 The timeline of changes in the proportion of foreign residents in the total population of the Sagrada Família and Poble Sec neighbourhoods compared to Barcelona as a whole (1991, 1996, 2001, 2004-2010) (Source: GRM, based on Continuous Census, Ajuntament de Barcelona; Cens de Població i Habitatge 1991, 1996, 2001, INE. IDESCAT)

region was from more distant Spanish regions. In the late 1990s and early 2000s, another inflow began, made up of international immigrants, mainly from Morocco, a variety of Latin American countries and Asian countries such as Pakistan and China (Fig. 5):

And just like in the 1950s and 60s or the 1930s we were a neighbourhood hosting other migrations, this time we have been a neighbourhood hosting these new immigrants. And we've withstood it, we have paid a price, of course we have paid a high price, because the last time we had many immigrants among us we put them on Montjuïc Mountain in cardboard or brick barracks. With totally unhealthy conditions, no medicine, no doctors, no schools ... Now it is different. Now what we have done is to shelter them among us. Maybe you knew that in your neighbour's house next door, ten people were living there, when maybe it was built for six... And this is the issue. We have paid the price of having them among us. But at the same time we did our best to prevent them from living in barracks, because it has not happened again. And we've worked with them. An important part of what the associative movement has done is trying to work with them... (B-PS-KI-11 Poble Sec, association member, 50 years old)

In Sagrada Família, according to the local continuous census, in 2010 the most numerous foreign nationalities were Italians (10.5\% of the foreign population), Peruvians $(8.3 \%)$, Chinese $(7.9 \%)$, Ecuadorians (6.8\%) and Colombians $(6.3 \%){ }^{6}$

\footnotetext{
${ }^{6}$ According to the Barcelona City Council's Statistics Department, in 2012 Chinese immigrants became the most numerous national group residing in Sagrada Família (908 inhabitants), followed by Italians (899) and Peruvians (625); see: http://www.bcn.cat/estadistica/catala/dades/inf/barris/ a2012/barri6.pdf.
} 
Table 2 Main foreign nationalities in the areas studied, 1.01.2010)

\begin{tabular}{l|l|l|l|l}
\hline Sagrada Família & Eixample district & Poble Sec & Sants-Montjuïc district & Barcelona \\
\hline Italy & Italy & Pakistan & Ecuador & Italy \\
909 & 5,538 & 1,357 & 3,187 & 22,684 \\
\hline Peru & China & Morocco & Morocco & Ecuador \\
779 & 4,143 & 1,012 & 2,372 & 22,210 \\
\hline China & France & Philippines & Pakistan & Pakistan \\
722 & 3,206 & 982 & 2,267 & 17,735 \\
\hline
\end{tabular}

Sources: http://www.bcn.es/estadistica/angles/dades/inf/barris/a2009/pdf/dte022.pdf (retrieved: 05.02.2011) and http://www.bcn.es/estadistica/angles/dades/inf/barris/a2009/pdf/dte031.pdf (retrieved: 05.02.2011)

On the other hand, in Poble Sec the first group were Pakistanis $(11.5 \%)$, followed by Filipinos (9.2\%), Moroccans (8.1\%), Italians (6.4\%), Dominicans (5.9\%) and Ecuadorians $(5.6 \%)$ (Table 2). ${ }^{7}$

In the next pages this official data will be compared with the perceptions of the interviewees.

According to the interviewed stakeholders, one of the main differences between the two neighbourhoods is that in Sagrada Família the immigrants are not very visible on the streets because of the massive presence of tourists, the wide main streets and the residential nature of the neighbourhood. The above-mentioned share of foreign population residents is not perfectly reflected by the actual perception of their presence in the neighbourhoods. In fact, alongside differences in figures, the two neighbourhoods also differ in terms of immigrants' visibility in public spaces. According to the interviewed stakeholders, in Sagrada Família the immigrants are not very visible on the streets since it is a touristic destination and a residential area with a limited number of public spaces and both characteristics have an impact on the visibility of immigrants because they become merged with the mass of tourists. On the contrary, in Poble Sec immigrants are very visible on some streets, as there are few neighbourhood users from outside both during the week and at weekends, and the heart of the neighbourhood is not crossed by wide traffic lanes.

Building on all these perceptions and statistics, and data from interviews with other local actors and other relevant sources of information, inter-group representations and behaviours in both neighbourhoods will be analyzed in the following sections.

\footnotetext{
${ }^{7}$ Also according to the Barcelona City Council's Statistics Department, in 2012 Pakistani immigrants were still the most numerous national group residing in Poble Sec (2,120 inhabitants), followed by Filipinos $(1,095)$ and Italians $(1,008)$; see: http://www.ben.cat/estadistica/catala/dades/ inf/barris/a2012/barri11.pdf.
} 


\section{Neighbours Talking About Neighbours: Who, What, and Where?}

In this section, the main inter-group perceptions and representations occurring in both Barcelona neighbourhoods will be analyzed.

\subsection{Sagrada Família: Dense but Cold}

As we explained, according to the official figures, Italians are the most numerous group of foreign residents in the neighbourhood. Nonetheless, they are not the most visible ones according to the neighbours interviewed. Besides general phenotypical reasons, this is due not only to the lack of clear distinguishability of this national group but also to the fact that a substantial share of such Italians are in fact Argentineans jure soli who have been able to enter Spain and settle there after acquiring Italian citizenship jure sanguinis as descendants of Italian emigrants.

Official statistics show Peruvians and Chinese as the next largest nationalities. Both of these nationalities are mentioned by interviewees as having a major presence in the neighbourhood. Peruvians are often included within larger categories such as 'Latin Americans' or 'South Americans'. Additionally, some interviewees also include Colombians, Mexicans, Ecuadorians and Argentineans as a part of those groups. Although frequently mentioned as being present in the neighbourhood, Mexicans are not in the list of main foreign nationalities. This might correspond with some interviewees' comments that a number of Latin American immigrants do not live in the Sagrada Família neighbourhood, but only work there.

Latin Americans are predominantly seen as 'the immigrants who have paid jobs'. They rarely own bars or shops, or are self-employed in other forms. Their presence is sometimes related to the ageing of the neighbourhood: many of them are in fact reported as working in the personal services sector, especially taking care of the elderly. In contrast to the apparently quiet Chinese community, young Latin Americans were portrayed by some informants as being responsible for noisy street life until late hours and the lack of safety on the streets. We should also mention that these allegations were not confirmed during the ethnographic fieldwork.

In contrast, Chinese immigrants are seen as a closed but peaceful community that does not cause problems in the neighbourhood. Still, it seems that the issue of the rapid growth in Chinese-owned commercial establishments is becoming a possible hot topic in the immigration debate within the neighbourhood. The Chinese residents' strong purchasing power and the supposed poor quality of their shops and products seem to be the most disturbing issues, especially, but not only, for native shopkeepers.

The other immigrant groups 'labelled' by interviewees as prominent in the neighbourhood are 'Muslims' (specified as Pakistanis and Moroccans), 'Senegalese', 
'East Europeans' (detailed as Romanians, Ukrainians and Russians), and 'European migrants' (mainly Italians).

Pakistanis are perceived as less numerous and somehow more socially open than Chinese immigrants. However, the general perception is that they, also, are a closed community:

A neighbourly relation between a Spanish woman and a Pakistani man is impossible in the neighbourhood. Between man and man, yes, there are some relations (...) For example: there is a Pakistani child in the school, and the school needs to speak with the parents. The mother never goes. It is always the father that responds to the call... The school director is a woman, and so there is no dialogue because the father needs to speak to a man. If there is no man, the dialogue ends. (B-SF-NF-34 Sagrada Família, social organization member, 44 years old)

Just like the Chinese, Pakistanis are known to run small businesses (mainly kebab joints and grocery stores) that are open long hours. They are also recognized as working in gift shops for tourists in the area of Sagrada Família cathedral. Their presence is not described using terms such as 'flood', but they are seen as a large group.

The so-called 'people from the East' (i.e. Belarusians, Ukrainians, Russians and Romanians) have a bad reputation related to alcohol consumption, conflict, a lack of safety and discomfort. Romanians are portrayed as perennial beggars and delinquents prone to committing petty crimes (Fig. 6).

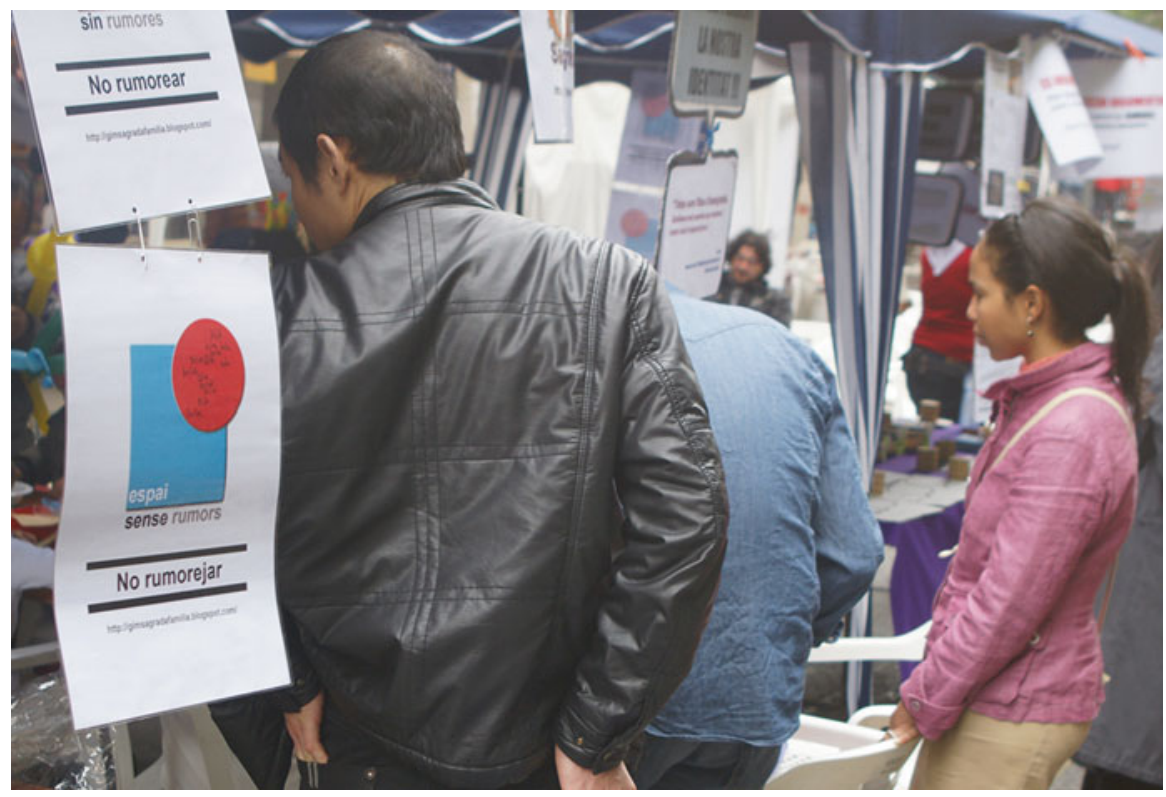

Fig. 6 Multicultural Interaction Group stall during a local street festival, a poster imitating nonsmoking signs announces a 'Space without [xenophobic] rumours' (Photo by D. Wladyka) 
The Sagrada Família neighbourhood is a tourist destination and residential area with a limited number of public spaces. Both characteristics have an impact on the visibility of immigrants, as they become merged with the mass of tourists. Concerning the opportunities of interaction, the daily and often superficial intergroup relations take place mainly in bars (mostly owned by Chinese and some Peruvians) and shops (grocery shops owned by Pakistanis and multi-purpose shops owned by Chinese):

If you walk through the neighbourhood [...] you notice that there are a lot of bars and restaurants [...] run by Chinese people [...] Peruvian bars, Colombian bars [...] None of them has a presence in the street $[\ldots]$ since this is a dormitory neighbourhood not for [social] life $[\ldots]$ This a very touristic neighbourhood [...] The [immigrants'] presence is not very obvious [...] In other sites you see it like: wow! But not here. (B-SF-KI-06-Sagrada Família, social organization technician, 34 years old)

There are no well-developed immigrant organizations in the Sagrada Família neighbourhood. There is a Chinese Evangelical church, but it does not seem to interact much with the other organizations in the neighbourhood. There were some attempts to set up a Peruvian immigrants' association, but ultimately it was transferred to another neighbourhood. In a way, it is possible to acknowledge a sort of isomorphism in Sagrada Família: the relative low degree of immigrant participation in associations is similar to the relative low degree of native participation.

However, some organizations have become meeting places for immigrants and natives alike. One example is the Multicultural Interaction Group (Grup d'Interacció Multicultural, GIM), ${ }^{8}$ an organization located in a socio-cultural space called Espai 210 that seems to be the most prominent of its kind in the entire neighbourhood (see Photos Figs. 7 and 8). Its core activities include organizing cultural activities and fighting stereotypes. Immigrants of Latin American origin (Peruvian, Cuban, and Argentinian) are especially active in the organization.

There is a space for newcomers' integration in the neighbourhood's public library. But what seems particularly important and effective in promoting integration is the coexistence in one single building of a public library, a civic centre, the local market place, social services, an excursionists' club and other organizations which are all located side by side. In this building, one can gain access to cultural and educational services, free internet, a variety of organized activities and everyday basics such as shopping. The result is an area of encounter that fosters everyday interactions, albeit often superficial, between immigrants and natives. Furthermore, some of the activities (e.g. Chinese New Year's celebration) held in the Civic Centre seem to also have a significant and positive role in promoting immigrant participation.

Some interviewees also noted the participation of immigrants in other organizations. Among them, we should highlight the Associació de Vë̈ns $i$ Veïnes de la Sagrada Família 9 (i.e., Neighbours' Association, providing mainly free Catalan

\footnotetext{
${ }^{8}$ See: http://www.gimsagradafamilia.blogspot.com.es

${ }^{9}$ See: http://www.avvsagradafamilia.net/
} 


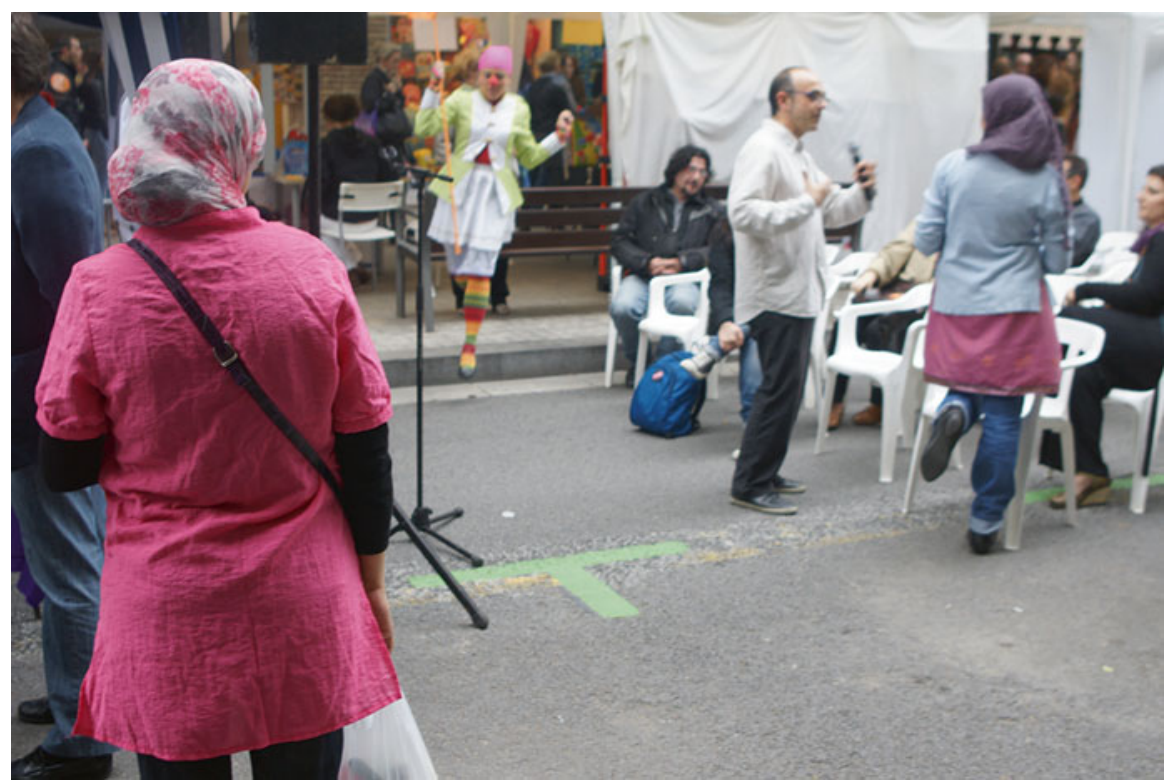

Fig. 7 Multicultural Interaction Group stall during a local street festival, a debate on multicultural interaction (Photo by D. Wladyka)

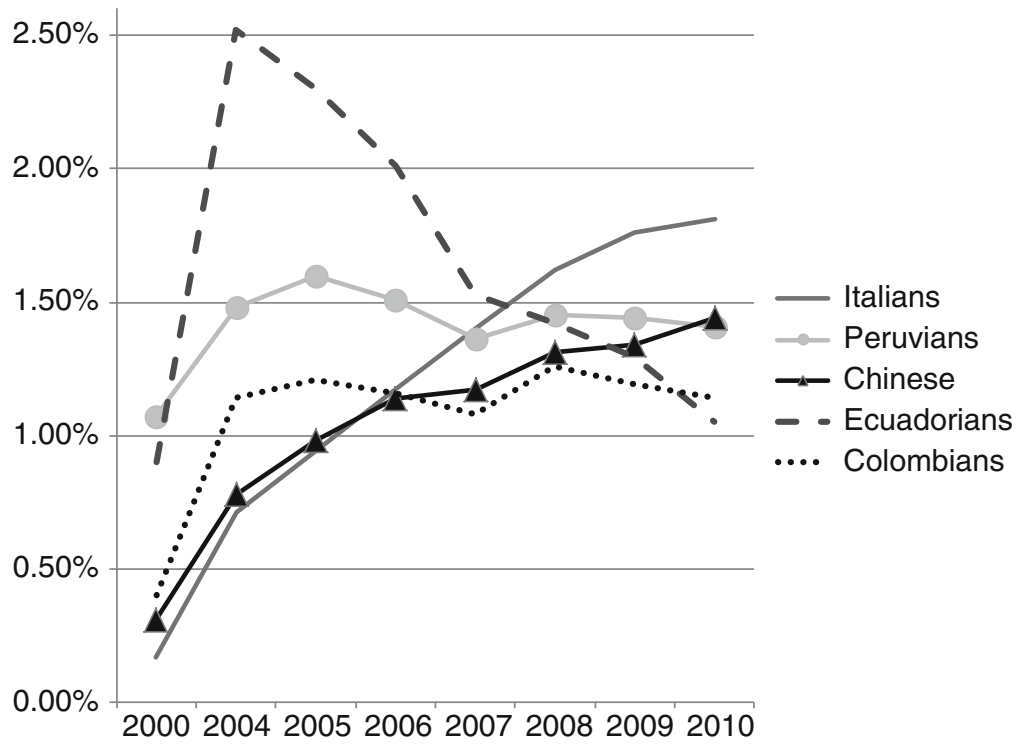

Fig. 8 Timeline of changes in the five most populous foreign nationalities (2010) in percentage of total population in the Sagrada Família neighbourhood (2000, 2004-2010) (Source: GRM, based on the Continuous Census, Ajuntament de Barcelona) 
language lessons), Aula Ambiental de la Sagrada Família ${ }^{10}$ (i.e. Environmental Classroom, located near the temple and offering activities and short courses on sustainability, etc.), Castellers de la Sagrada Família ${ }^{11}$ (the traditional Human Towers movement, where immigrants and natives can climb on each other's backs to form human pyramids), as well as language and music schools in the neighbourhood. However, there are differences in participation by national groups. The perceived explanatory elements are manifold, with national origin as a decisive variable. Chinese immigrants are perceived as the least participative, and Latin Americans are seen as the most actively involved in the life of the neighbourhood. The interviewees put this down to differences in linguistic skills, cultural background, daily working hours and knowledge about how the neighbourhood operates, which is dependent on length of residence.

The ones from South America participate, although not the young ones but those who are mature $[\ldots]$ they probably have already spent some time here $[\ldots]$ they know how the neighbourhood works. (B-SF-KI-03-Sagrada Família, socio-cultural activist, 28 years old)

Generational belonging also seems to matter. The informants noticed that the second generation of people of Chinese origin do relate more to natives. They go to schools with natives and other immigrants and maintain friendships with them:

You cannot see them shopping in the stores [...] maybe now you can start to see it $[\ldots]$ some young Chinese girls do, sometimes; I saw one buying in the shops, in the market [...] so you say it is not so bad. (B-SF-I-01-Sagrada Família, shop keeper \& traders' association, 51 years old)

The Chinese do not participate a lot. But I had a Chinese classmate in the Catalan language course. The girl was completely integrated. You can find all kinds of people. (B-SF-NF-31Sagrada Família, social organization member, 64 years old)

Finally, the third element cited by interviewees to explain immigrants' participation in civic life is the type of organization: traditional organizations such as Castellers and the board that organizes local traditional festivities seem to attract immigrants' attention and participation the most; in contrast, the shopkeepers' or excursionists' associations seem to be ignored by immigrants. Two main reasons for this different degree of participation arose from ethnographic observations. Firstly, organizations such as the Castellers and the committees of the local traditional festivities are usually the most popular organizations in the neighbourhood among both younger and older residents, whereas the shopkeepers' associations in the neighbourhood are visibly divided and often have distinct aims that cannot be easily understood by new or prospective members. Secondly, while there is a fee for participating in shopkeepers' and excursionists' organizations, participation in traditional activities, Catalan language courses or other short courses is often free of charge.

\footnotetext{
${ }^{10}$ See: http://aulambientalsf.blogspot.com.es/

${ }^{11}$ See: www.castellerssagradafamilia.com. Furthermore, for a general introduction to the importance of the human towers movement regarding foreign immigrants' integration in Catalonia, also see Morén-Alegret (2007).
} 
In any case, the lack of participation is not exclusive to immigrants: the interviewees generally saw young people as not participating. Therefore, the intergenerational gap is relevant in terms of inter-group relations. In many organizations, such as the Neighbours' Association, it became quite visible during the ethnographic observation that the majority of day-to-day active participants are elderly or mature people. There seem to be many reasons for this situation, such as the fact that some important organizations are controlled by the same group of neighbours for years on end. Another related reason could be the lack of openness to new ideas and to young people.

Another issue related to inter-group representations in Sagrada Família has to do with formal education. Some interviewees noted that recently most students in public schools appear to be immigrants or immigrants' children. According to them, native people tend to go to semi-private ${ }^{12}$ schools because immigrants 'lower' the level of public education. Immigrant students in private or semi-private schools are mainly from China because they can afford it. Latin Americans and Africans primarily attend public schools:

I had five or six [foreign classmates] in a class of twenty-five people. My brother had over $50 \%$ [...] Immigrants lower the schooling level. It is somehow ugly to say it... but it is true. (Sagrada Família, B-SF-KI-10-sports instructor \& cultural organizations member, 24 years old)

The perception of the increasing number of immigrants' children in the public schools corresponds with the data about the average household age according to nationality. The households made up of foreign members are, on average, 17 years 'younger' than Spanish nationality households. However, while immigrants' households are relatively younger than the rest, their number is not high enough to explain the perception that schools are being 'flooded' with foreign immigrants. This can be seen in the statistics about the proportion of young foreigners to the total population in their age group, which does not show an especially high number of foreign youths. In particular, during the last 4 years, this figure did not exceed $20 \%$ in any of the age groups. The primary data about schooling in Barcelona shows that 4 out of 16 public schools and 2 out of 29 semi-private schools in the Eixample district have more than $30 \%$ foreign students. The data on the education of the children between the ages of 3 and 16 show that most of the foreign students are from Latin American and Asian backgrounds (Consorci d'Educació de Barcelona 2010). The difference between the number of immigrants' children in the neighbourhood and the perception of their increasing presence in public schools might be tentatively explained, based on the fieldwork, by the greater popularity of private and semiprivate schools among native parents (also those located in other Eixample neighbourhoods) than among immigrant parents. However, further research and analysis focused on this specific issue should be carried out in order to provide comprehensive explanations.

\footnotetext{
${ }^{12}$ In Catalonia and other Spanish regions, there are numerous semi-private schools known as 'escoles concertades'. They are privately run schools co-funded by the regional government. In this way, the regional government may have a say in some 'escola concertada' issues. The fees are lower than in private schools but higher than in public schools.
} 


\section{Box 1: 'Encants Vells': No-man's Land}

One of the Sagrada Família areas specifically studied during the project was 'Encants Vells' (in Spanish, 'Encantes Viejos'). This toponym refers to its most significant place: the homonymous open-air flea market. A common feature of the area is the perception that it is distinct and somehow outside both Sagrada Família and other surrounding neighbourhoods. Some people who work or live in the area even describe it as 'no-man's land'. According to some neighbours, foreign immigrants have had a major impact on the area in the last decade. There are four key issues that residents see as problematic which they relate to the increasing number of immigrants: (a) Illegal street vending is described as littering the area and increasing the sense of insecurity. Moroccan, Senegalese and Romanian immigrants are mentioned as participating in this activity; (b) The squatted houses and supposedly illegal warehouses are described as areas with no control, inhabited by suspicious people, creating noise and fire hazards and littering the area. Immigrants from other European countries - especially Portugal and Romania - and Morocco as well as some natives are mentioned in this context; (c) Robberies and assaults on the streets are described as alarming, but they are regarded as rare incidents. Moroccan immigrants and natives are mentioned as delinquents in this context; (d) Overpopulated flats, mostly rented by immigrants, are cited as being disturbing to other neighbours and creating unhygienic conditions. It is important to mention that although residents of Encants Vells are disturbed by the aforementioned issues, they believe that the area is less dangerous than those who live in other parts of the neighbourhood think. Nevertheless, the interviewees related to Encant Vells often ascribe the illegal street vending and robberies to some residents in this area. These activities are often explained by the current economic crisis, which is described as being equally challenging for both immigrants and natives. Finally, for some interviewees, there is lack of interaction between native and immigrant neighbours since the flea market attracts a lot of outsiders and it can hardly be considered a neighbours' area of encounter. It will be interesting to analyze the evolution of the area after the opening of the new flea market in Autumn 2013 (see: http:// www.encantsben.com) and the renewal project of Glories square planned for the 2014-2018 period (see: http://glories.ben.cat).

\section{2 'Caliu de Barri': Dense and Warm Poble Sec}

When considering Poble Sec inter-group representations, the differences between the immigrant communities in the neighbourhood seem to be a relevant issue. According to most interviewees, Moroccans, Pakistanis, Dominicans and GypsyRomanians stand out as the most numerous groups in Poble Sec. This observation is relatively accurate: as we explained above, according to official data, as of 1 January 
2010, Pakistanis were the largest group of foreign nationality in the neighbourhood with 1,290 inhabitants, followed by Filipinos and Moroccans. We should furthermore consider that many shops in the Poble Sec neighbourhood are owned by Pakistani immigrants, which makes them quite visible in the streets and increases residents' perception of their presence. Dominicans, also perceived by the interviewees as one of the most numerous nationalities in the neighbourhood, rank fifth behind Italians. It is interesting to note, in this respect, that Dominican immigrants are often regarded as 'South Americans', although the Caribbean is obviously a distinct and profoundly different entity from the South American continent. Other residents attach the label 'Latin American' to all immigrants from former Iberian colonies in the Americas as a whole. In the same way, sometimes the interviewees confuse Filipinos with Chinese nationals, or they are grouped under the umbrella of 'Asians' without people knowing their exact country of origin.

In contrast, the interviewees' perception regarding Romanians seems to be quite inaccurate. There are only 177 official residents with Romanian nationality but they often popped up during interviews and conversations with residents.

Figure 9 shows the evolution from 2000 to 2010 of the ten most populous foreign nationalities in Poble Sec in 2010. It should be noted that all the nationalities have risen in numbers, but nationalities such as Moroccans, Dominicans and Colombians have undergone different fluctuations throughout this period. The increase in the number of Pakistanis is especially noteworthy, with a spectacular influx during the first part of the decade. The rise in Filipino immigrants over these years is also

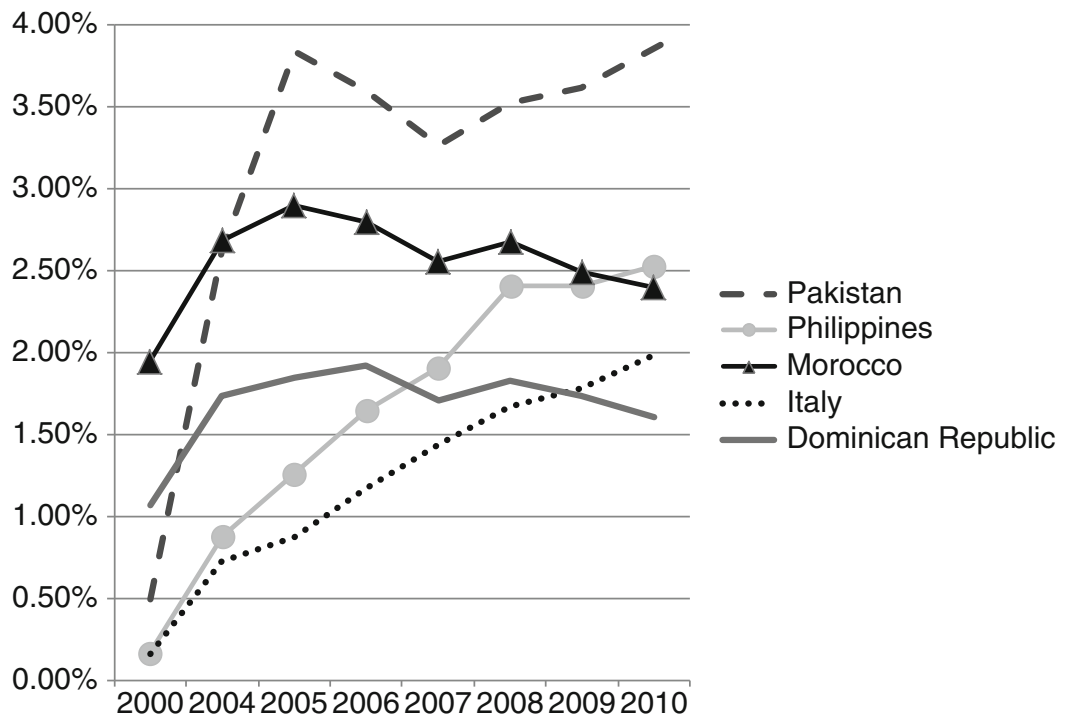

Fig. 9 Timeline of changes in the five most populous foreign nationalities (2010) in percentage of total population in Poble Sec neighbourhood (2000, 2004-2010) (Source: GRM, based on data from the Continuous Census, Ajuntament de Barcelona) 
remarkable. It is worth underlining that among the top nationalities, they are the ones mentioned least often in the interviews. Sometimes the interviewees confuse them with Chinese nationals, or they are grouped under the umbrella of 'Asians' without people knowing their exact country of origin. A similar case, although to a lesser degree, occurred with some interviewees when talking about South American nationalities.

Shifting to the content of perceptions on different groups, the general perception of Pakistanis is that they are regarded as being mainly concerned with their businesses and there is no conflict between them and the natives or other immigrant collectives. For instance, a man aged 58 who has lived in Poble Sec since he was 10 years old, mentions the Pakistanis as 'positive immigrants', in contrast to other nationalities:

These ones [Pakistanis] don't cause problems. The problematic ones are the others $[\ldots]$ [Pakistanis] open at $8 \mathrm{am}$ and close at midnight, but well, they do not cause problems.

(Poble Sec, B-PS-KI-2-neighbours' association, 58 years old)

Although it is difficult to speak with Pakistani residents, they seem to corroborate the idea that they are almost only concerned with their jobs and businesses. In this sense, when asked about the neighbourhood's situation, an immigrant from Pakistan, the owner of a grocery shop, said:

If you just come here to work, it doesn't matter what the neighbourhood is like. (B-PS-I-9Poble Sec, Pakistani grocery owner)

In a similar vein, when asked to draw a map of the neighbourhood, another Pakistani immigrant who owns a similar business added the following:

I don't go out [of the grocery shop]. I stay here inside...people buy... (B-PS-I-7-Poble Sec, Pakistani business owner)

Both of these representatives of the local Pakistani entrepreneurial middle class share the natives' annoyance over problems of noise and dirtiness on Blai Street, as well as the perception that Dominicans are a prominent presence on that street. It is also worth quoting a few words from a more socially integrated Pakistani shop owner who participated in the Neighbourhood Forum:

I do participate in the shopkeepers' association of Poble Sec-Associació de Comerciants del Poble Sec - (...) the neighbourhood has improved a lot. I arrived [from Pakistan] in 1996 and I started my business in 2002 (...) A person who comes anew, with another skin colour, people treat you differently, of course. 'Ah, these newcomers, who knows what they are like...', this is normal. Later, as time goes by and people visit your business, they start to get used to us, and now they are already used to us. (B-PS-NF-42-Poble Sec, shopkeepers' association member, 38 years old)

A different perception arises when talking to residents about Latin American communities, especially regarding the Dominicans who are often strongly stigmatized. For instance, the same 58-year-old man quoted above claimed that there are no problems at all with the other communities, but

the problematic ones are the South Americans [...] People here want these people to get integrated. But they do not want to integrate... No, I don't know if it is their culture, or a lack of will, or ... I don't know. (B-PS-KI-2Poble Sec, neighbours' association, 58 years old) 
Some Dominican immigrant leaders even see this street life issue as a challenge to overcome:

The street life is really the main issue. To be truthful, street life brings a lot of joy to the neighbourhood and a lot of headaches too, both to the neighbourhood and to the community [...] In the case of Dominicans, I would say that our street life brings a lot of headaches because it is true that it sometimes causes a disturbance... [...] People like me who have a business do not support those people who are in the street, I do not support them... (Poble Sec, B-PS-NF-40-shopkeepers' association member, 37 years old)

The last quotation confirms that Dominicans are far from being a homogenous group (as natives too often tend to assume) and that their degree of internal solidarity, their behaviour and (self) perceptions may vary enormously.

As noted above, Poble Sec is characterized by a powerful associative network and a so-called 'friendly atmosphere' that contributes to relatively strong ties among many residents. In this sense, spaces such as the Civic Centre 'El Sortidor' play a key role in socializing processes and inter-group relations (see Photos Figs. 10 and 11).

As we explained above, Poble Sec has had a history of welcoming new waves of immigrants over the past last two centuries. These factors are supposed to have contributed to a satisfactory integration process into Barcelona society, helping to overcome conflicts and facilitating cooperation.

On the other hand, it should be taken into account that the 'friendly atmosphere' of the neighbourhood can also become a potential source of conflict. The changes

Fig. 10 Civic Centre 'El Sortidor' (guia.ben.cat) (Photo by A. Mas)

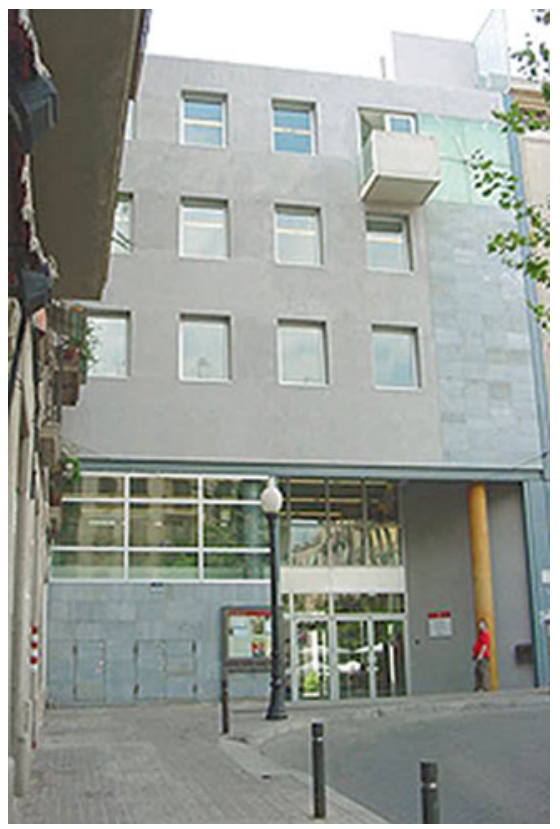




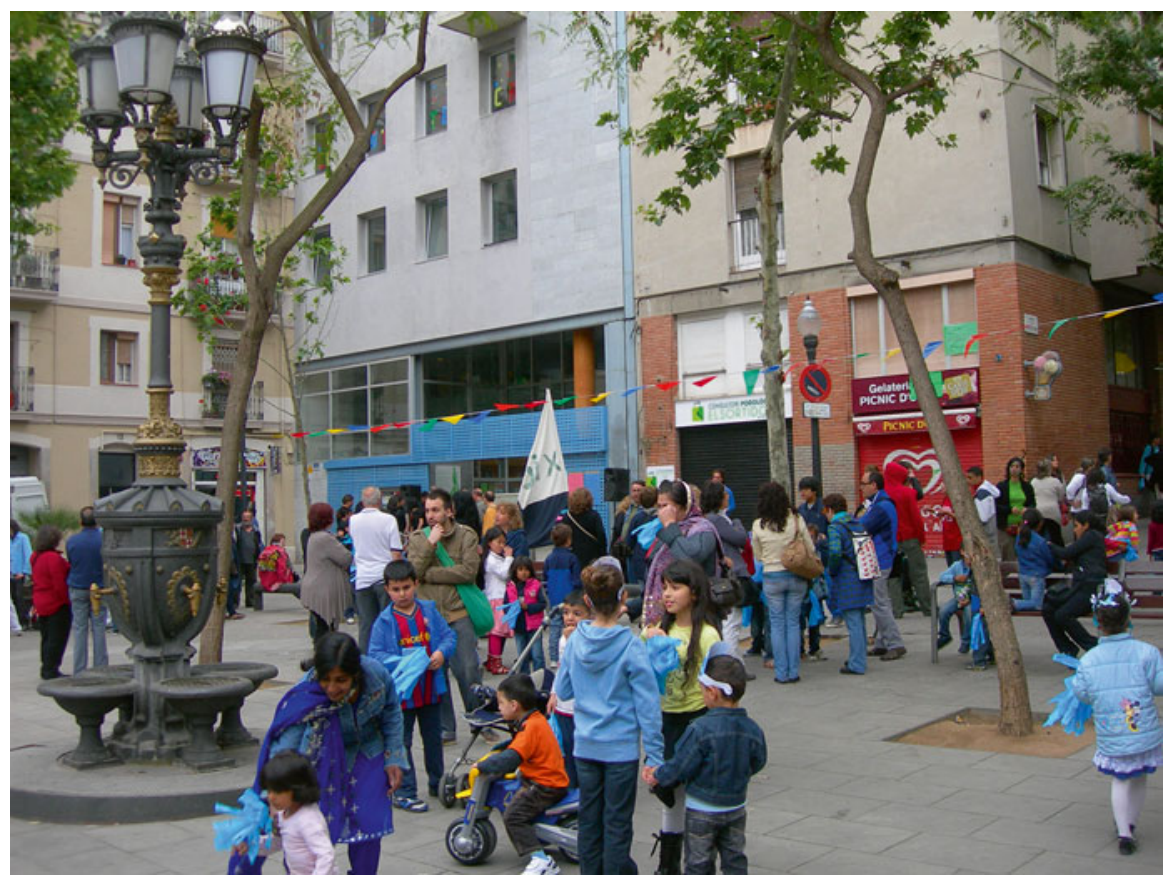

Fig. 11 Plaça del Sortidor during an activity organized by the Community Development Plan, 2011 (Photo by A. Mas)

triggered by the arrival of newcomers can be seen as a threat to this 'friendly' atmosphere, neighbourhood life or the aforementioned 'caliu de barri'. 'Caliu de barri' goes beyond mere representations, as it also pertains to actual social relations. It may mean that you come across and greet the same people in your daily life in the neighbourhood. It means that native neighbours can get used to their foreign neighbours more quickly and easily and, consequently, false stereotypes can be eliminated more easily. The same can happen among foreigners, who can also get used to their native neighbours or other foreign neighbours more easily. On the other hand, if some neighbours do not like or do not tolerate the attitudes or activities of specific neighbours or groups of neighbours, this 'caliu de barri' can play a negative role, facilitating conflicts or fuelling the growth of latent conflicts.

In other words, a strong local identity and social cohesion, a powerful associative network and a so-called 'friendly atmosphere' contributing to relatively fluid relations among some neighbours are regarded by some interviewees as positive factors for integrating their residents and as a sort of vaccine against possible exclusion processes. But, on the other hand, those same characteristics of the neighbourhood may also cause some native neighbours to view the arrival of a new population as an intrusion on the so-called 'friendly atmosphere' (until they may get to know the newcomers). 
Specific issues such as noise and dirt in the streets were mentioned in the interviews as potential sources of conflict. However, these issues do not exist in isolation. As underlined by a 28-year-old woman who is a member of a local association, some people explicitly say that arising conflicts are often linked to both the arrival of immigrants and the lack of policies aimed at improving interrelations between communities. However, this interviewee expressed doubts about linking this issue to the arrival of foreigners and suggests another explanation that is more closely related to socio-economic aspects:

I would link the cleaning issue to ... rather than immigration, it can be linked, I don't know, maybe I'm going to say something politically incorrect, but I associate it with a low socioeducational level. You know, not showing respect, not valuing having a clean place, not considering the fact that having a person coming to sweep once a week costs money, right? So, many times the profile of newcomers who come is people - as is logical, this is not a criticism - who have a low socio-educational profile and therefore do not value the public space the way other people do. But this has always been a working-class neighbourhood, so I don't think immigrants are the ones [to blame]... [...] It is not the fact of immigration, but the failure to take care of the place where you live. (Poble Sec, B-PS-KI-3-association member, 28 years old)

Another source of conflict that appeared in some of the interviews is the feeling that there is a lack of safety in the neighbourhood. But looking at the number of crimes per 1,000 inhabitants in 2009, we can observe that the Sants-Montjuïc district (6.1) has lower numbers than the Eixample district (8.2) and the Barcelona average (7.07). ${ }^{13}$ It is also worth mentioning that both districts have much lower crime rates than the Ciutat Vella district, which has the highest crime rate in Barcelona city (33).

Some of those interviewed thought that the perception of a lack of safety and security in Poble Sec is linked to the increase in the foreign population. According to some stakeholders, having more police officers patrolling could change that perception. In fact, some interviewees related an improvement in safety and security problems during recent years to an increased police presence and a better attitude among residents.

Divergent opinions about immigration can themselves become a source of conflict along ideological lines among natives. For example, a 28-year-old woman who belongs to a neighbourhood association quite clearly describes two contrasting and seemingly opposed visions that can be voiced by individuals with close relations and, in some cases, by the same individual:

At the same time they say [...], that life is much better. That years ago there were many more problems of.... I don't know if I should use the word delinquency, but of drug use, of .... Well, you know, such as some social unrest, the old residents say. And they say that now life is so much better. But there are others who say that, obviously, with so much immigration, the neighbourhood is in a very bad situation. (B-PS-KI-3-Poble Sec, Association member, 28 years old)

\footnotetext{
${ }^{13}$ Data is not available at the neighbourhood level.
} 
Cultural differences are sometimes perceived as potential sources of conflict. This issue becomes particularly important when talking about residents of Latin American extraction, especially Dominicans, due to their particularly pervasive daily presence on the street. Different ways of life, more intensive everyday uses of the street, engaging in louder conversations and enjoying louder music are just some of the behaviours noted by some interviewees to explain controversies regarding Dominican immigrants.

\section{Box 2: Tres Xemeneies Gardens: A Multifunctional Space at the Edge of the Hood}

The Three Smokestacks Gardens (Jardins de les Tres Xemeneies, JTX) was one of the areas studied in Poble Sec. This interaction site is frequented not only by residents, but also by passers-by, such as office workers and patrons of theatres and disco-clubs. Skateboarders, mostly young males, are one of the most visible groups of users. Most of them live elsewhere. Some are tourists or temporary residents. Every day, there are several skateboarders in the park. Still, it seems that they do not interact with the rest of the neighbourhood and barely interact with other JTX users. Another key collective is made up of residents who go to the park to relax, read, stay outside, have a chat, etc. This group includes various genders, ages, and nationalities. The elderly are the majority among them, and they express discontent with the skateboarders' presence. The users of the 'pétanque' courts situated here are also mostly elderly and may have similar feelings regarding the skateboarders. Parents that visit the park with children are the third group of daily users. Although some are residents of the nearby Raval neighbourhood, most of them live in Poble Sec. The children's playground is where peaceful coexistence can be replaced by closer ties and deeper interactions. Another collective that frequently uses the park consists of Muslim youngsters - mainly of Pakistani origin - who use the football and basketball courts to pray on Fridays. Although some of them sit on the benches before and after praying, they barely interact with others, but do not cause any problems either (this situation is different than in other cities, perhaps due to the fact that this park is relatively big and separated from houses and commerce and, additionally, the intense car traffic in Parallel Avenue puts a noisy veil to Friday's Muslim soundscapes). Pakistani immigrants also used to gather here to play cricket at the weekend, but recently they prefer the distant Forum Park. Celebrations, festivals, concerts, etc., involve neighbourhood residents and associations, but usually attract people from other neighbourhoods and even other cities. Latin American and Pakistani associations, among others, have also held events here. Several interviewees believe that there are too many activities here, and this high demand can raise conflicts. Also youth drinking alcohol in JTX at the weekend is an emerging issue linked to the park's location in a popular nightlife area (that also produces noise and refuse). However, the biggest 
Box 2: (continued)

conflicts are related to the presence of the homeless and to the dealing and consumption of drugs. Although the two issues are not necessarily linked, the interviewees usually relate them both to insecurity. According to several interviewees, some of the homeless are foreigners, mainly from Eastern Europe (especially Romanians), and they relate those homeless immigrants to security problems. Although these opinions cannot be generalized, it should be noted that even the interviewees with positive opinions on the neighbourhood, point to JTX as being a problematic spot at times.

\section{4 (Un)Covering the Neighbourhoods: Bad News Sells Best}

As in the research undertaken in other target cities of the Concordia Discors project, an additional research tool we used was a quantitative and qualitative media analysis, based on a sample of the contents of two newspapers over the previous decade. Issues of La Vanguardia and El Periódico de Catalunya were surveyed from the years between 2001 and 2010 to see how often the target neighbourhoods were mentioned in association with immigration and to identify the dominant representations of inter-group relations and policy interventions on immigration and integration issues in the target neighbourhoods. ${ }^{14}$

The coverage of immigration in the local media we analyzed has become more intensive over time: the number of articles with references to immigration per year for each neighbourhood grew in the second part of the decade, in parallel with the growing percentage of immigrants living there. More attention was paid to immigration issues in Poble Sec than in Sagrada Família: 41 out of 248 articles dealing with the former include references to immigrants (16.5\%), whereas this percentage is much lower in the case of Sagrada Família (30 articles out of 634 articles, equivalent to just $4.7 \%$ ). Several interlinked explanations can be suggested. First, there are factors related to the importance of the Sagrada Família cathedral within the city, which makes it a news item in itself. The second factor may be the different percentage of foreign residents in each neighbourhood (27.9\% in Poble Sec as opposed to 'only' 16.8 in Sagrada Família) which is understandably reflected in the intensity of targeted coverage. A third factor might be that Poble Sec is a working-class neighbourhood with an average income significantly lower than that in Sagrada Família, so the social service needs of the neighbourhood are greater than in other neighbourhoods. The arrival of immigrants with lower incomes, 'impoverishes' the neighbourhood in income or economic terms and fosters perceived competition

\footnotetext{
${ }^{14}$ For more details about analyzing these two newspapers and the methodological aspects of the media analysis, see the Barcelona Final Report at the Concordia Discors project web page: www. concordiadiscors.eu/
} 
between natives and immigrants, which attracts media attention. Fourthly, the location of Poble Sec, which is very near the so-called 'conflictive' neighbourhood of Raval, is also a relevant factor. At times, this geographical proximity can contribute to spreading social alarm from Raval to Poble Sec.

The analysis also showed that the two newspapers pay more attention to conflict than to cooperation when covering immigration. This is true in both neighbourhoods, but especially in Poble Sec and especially in reference to conflicts related to poverty, degradation of public space, insecurity, dirtiness, coexistence and accident and crime reports. It should be said that some of the articles featuring Poble Sec highlighted economic, social and cultural cooperation.

In the Sagrada Família neighbourhood, the interviewees primarily believe that the neighbourhood's everyday life or its problems are not sufficiently covered by the media. According to the interviewees, the neighbourhood only appears in the media when there are events or problems related to the Sagrada Família cathedral itself. The only exception to this rule is the outrageous crimes that take place in the neighbourhood from time to time. Several neighbours noted that the media do not mention immigrants' supposed involvement in conflictive issues related to the neighbourhood because of 'political correctness'. On the other hand, in Poble Sec, most interviewees complained that the neighbourhood usually appears in the mass media in connection with negative news, as shown, for instance in the months before the ethnographic fieldwork, by the very intensive coverage of a case involving a gang of thieves operating in the underground network.

Last but not least, we should mention the neighbourhood newspaper ZonaSec (www.zonasec.cat/). This monthly newspaper is managed by the Coordinadora d'Entitats del Poble Sec (the umbrella organization including most associations based in Poble Sec) and it has been in circulation for over 15 years. During the interviews, ZonaSec was mentioned as a positive factor for cooperation and resolving conflicts. This newspaper is distributed for free at the neighbourhood level in a variety of places, and it counteracts the role played by some mass media, which normally pay attention to the neighbourhood only when there are sensationalist news stories offering a negative image of Poble Sec and its foreign population. This newspaper is very popular among the neighbourhood's residents and some regular visitors, and almost all the interviewees mentioned it when we asked them about the media issue. In Sagrada Família, there is no neighbourhood newspaper comparable to ZonaSec.

As a final reflection, we should note an apparent paradox that emerged from the media analysis. On the one hand, there seems to be a general social agreement among the media, residents and the policy community about the need for cooperation and integration policies. However, on the other hand, interviewees frequently emphasized that conflict is flashier and sells more newspapers than cooperation or reflection about policies. 


\section{A Growing Demand for More Spaces of Encounter}

Barcelona is increasingly an actor on the international stage for a number of reasons, including assets located in or around demographically dense neighbourhoods like Sagrada Família and Poble Sec. As described and analyzed throughout this chapter, the two neighbourhoods examined in this study have a number of differences and commonalities that are worth reviewing here in order to point out the main explanatory factors.

In the Sagrada Família neighbourhood, both cooperation and conflict between groups are rather scarce, and they are not as important to the neighbourhood's life and the residents' perceptions as in Poble Sec. While the difference in the percentage of foreigners is an important factor, the urban fabric is equally crucial. The wide streets with heavy through-traffic in the Sagrada Família neighbourhood are seen by the residents as significant obstacles to the development of the neighbourhood's social life. The dearth of open public spaces, the spatial configuration of the open spaces that do exist which make them unconducive to activities, and their occupation by massive influxes of tourists are other characteristics of the neighbourhood that hamper neighbour-to-neighbour relations in Sagrada Família. In fact, the Eixample district as a whole would need a kind of 'central park' in order to foster social life and outdoor activities. ${ }^{15}$ In contrast, in Poble Sec, the neighbourhood's narrow streets invite or even force people to interact. ${ }^{16}$ The general lack of conflict in the Sagrada Família neighbourhood does not amount to a positive example of cooperation; rather it can be better understood as a consequence of scarce interactions. Importantly, the few large public places that do exist - Gaudí Avenue, Gaudí and Sagrada Família squares, and Encants Vells flea market - still seem to provoke multi-layered conflict rather than cooperation between residents and outsiders (tourists, street-sellers, etc.) and between native and immigrant residents. Furthermore, the lack of 'sharp' boundaries of the centrally located Sagrada Família neighbourhood, together with the very good transport connections to other parts of the city, have contributed to a weakening of the neighbourhood's identity.

As noted at the beginning in this chapter's introduction, previous studies have associated the working classes with the concept of 'community', in contrast to the more individualistic and relatively less place-attached middle classes (Halfacree and Boyle 1993). Our findings are consistent with such assertions. The aforementioned features in Sagrada Família, coupled with the 'bedroom community' and lower-middle class nature of the neighbourhood have limited the development of social networks there. In contrast, the Poble Sec neighbourhood is a working-class area with a strong local identity, clear boundaries and rich social networks that are

\footnotetext{
${ }^{15}$ For some, the renewal projects of Glories Square aim to develop a kind of Central Park there, see: http://ccaa.elpais.com/ccaa/2014/01/10/catalunya/1389388248_623867.html and http://hicarquitectura.com/2014/02/agence-ter-ana-coello-de-llobet-1r-premio-concurso-plaza-de-les-glories-barcelona/ ${ }^{16}$ According to plans, the future reform of Parallel Avenue will develop several new squares along this key Poble Sec boundary, see: 'El nou Paral · lel', La Vanguardia, 9 January 2014.
} 
important agents of inter-group relations. The 'community' feeling expressed by the Poble Sec stakeholders and informants is very strong.

Due to the aforementioned 'intensive' interactions and street life in Poble Sec there are more chances for cooperation but also for conflictive situations. At the same time, this greater 'opportunity' for conflict provides greater opportunities for solving both implicit and explicit conflictive situations than a context of peaceful coexistence, thus confirming the idea of 'concordia discors' that forms the basis of this book (see Introduction). In this sense, one can argue that a 'peaceful' neighbourhood where individualism or group separation is the norm needs more cooperation in order to be socially sustainable in the long run, otherwise it may become a social desert where tensions are hidden rather than resolved.

In accordance with this idea, in both Barcelona neighbourhoods, public places appear not only as areas of encounter, but also as areas of multi-layered conflicts over their use, which directly influence inter-group relations: in various cases, the space as such constitutes a context for various dimensions of conflict, mainly cultural, demographic and economic. As Tim Creswell (1996) notes, studying the relation between place and behaviour helps to identify behaviours that are judged as inappropriate or out of place in a particular location. Furthermore, the kind of conflict that seems to trigger the most emotional responses is based on behaviour in public places: loud music, talking and yelling during the night or quarrels which involve particular groups of users of the space seem to bother many residents.

Place and space do not only play a secondary role as the setting of the interaction; rather the configuration of areas where encounters occur has a significant influence on conflict and cooperation in the neighbourhood. Thus, a clear practical recommendation emerging from our research is that immigrants' integration policies should be designed with space and place in mind not only as settings but also as objects of those same policies. These social policies could be inspired by what some planners have been doing deliberately when creating or preserving "memorable and singular structures to make a space distinctively different $[\ldots]$ to encourage in the residents an attachment to that place' (Mayhew 2004: 444).

While during some interviews the different national origins of immigrants were evoked in order to indicate their supposed 'guilt' and to underscore their cultural 'otherness' as a source of conflict, some interviewees are aware that explanations for some immigrants' 'unusual' behaviour can lie beyond the bounds of nationality: their focus is not on the national origin but on the geographical origin. As highlighted by previous research (Morén-Alegret 2008), the transfer from rural or mountainous sparsely populated areas to a densely populated metropolitan neighbourhood is underlined as a problem in some cases because in such places the definitions of 'polite' and 'rude' behaviours and 'street life' differ. This finding is in tune with previous research on senses of place and migration (Mendoza and Morén-Alegret 2013).

In other cases, age difference is another acknowledged explanation. Native elderly are often very impervious to changes (such as evening activities, musical events, bars being open long hours, street-life culture) brought about by young residents and other 'innovators'. But such resistance seems to be driven by generational 
factors much more than cultural or ethnic ones. Economic status is yet another explanation, and the lack of jobs and other productive activities is often mentioned as a factor that brings youth to public places, where they hang around spending their daily lives in ways that are often criticized by other neighbours.

On the other hand, the interactions found in those areas of encounter are of varying depths. They range from a rather superficial level, such as daily use of the library or the marketplace, to more profound levels in cases such as organized seminars, courses or working groups. In general, goal-oriented public spaces and organizations which are seen as providing tangible benefits attract immigrants' attention. In the same way, when immigrants perceive that participation offers added value, it is especially appreciated. Immigrants and native youth alike seem to avoid organizations with tight hierarchical power structures that are not open to new input and ideas. Another important variable is the cost of participation. Organizations with expensive membership fees seem to attract immigrants less than groups without fees or with low fees. Still, this is probably more a collateral effect of the current economic crisis and general social class divides than a question of specific geographical origins.

The importance of civil society organizations is another crucial factor in shaping inter-group relations (Joly 1998; Morén-Alegret 2002b). The existence of a closeknit coordinated associative network of social organizations at neighbourhood level can be seen as a very useful tool. Firstly, it can facilitate the settlement process of the foreign-born population; secondly, it can contribute to managing and solving conflictive situations; and, thirdly, when it is impossible to find a quick solution to a neighbourhood problem, the associative network can work as a 'safety-valve' institution leading 'to a displacement of goal in the actor' (Coser 1956). As Lewis Coser argues, in the latter cases, when the coordinated associative network acts as a safetyvalve institution, it helps to release tensions: the social actor 'needs no longer aim at reaching a solution of the unsatisfactory situation, but merely at releasing the tension which arose from it ... the conflict itself is channelled away from the original unsatisfactory relationship into one in which the actor's goal is no longer the attainment of specific results, but the release of tension' (Coser 1956: 155-156).

In fact, it should be taken into account that these associative networks have been performing functions that, in another time or another country, would be performed by the public administrations. This network of social organization is especially prominent in the Poble Sec neighbourhood and, to a much lesser extent, in the Sagrada Família neighbourhood. However, in general, the generational replacement in these associations and the cuts in funding due to the economic crisis are key challenges for the future.

Besides civil society organizations, schools, public libraries and civic centres emerge as spaces where encounters and interrelations take place in both neighbourhoods. Commercial relations, especially in little grocery shops and 'bazaars', have also been identified as being important for interethnic relations. In the specific cases of the Chinese and the Pakistani communities, both communities that are often perceived as being quite 'closed' beyond the economic sphere by the rest of the population, ownership of numerous businesses in the neighbourhoods has contributed to bringing them closer to some of their neighbours, albeit often in a superficial way. 
To conclude, we must once more emphasize the importance of maintaining projects that have been working to improve the social situation in both Barcelona neighbourhoods in the future. In particular, the Community Plans and public facilities such as civic centres and public libraries have been performing crucial tasks during a period during which millions of foreigners arrived in Spain, and their efforts have helped both natives and immigrants' social integration at the neighbourhood level. We are left wondering what mid and long-term effects current economic policies will have on social cohesion, based, as they are, upon sharp cuts in public and private funds to community projects and organizations active in the field of integration.

Last but not least, another issue concerning general city policies, which strongly impacts on inter-group relations at neighbourhood level, is tourism, which is raising other issues beyond the ones pointed out when analyzing the Sagrada Família case study. Today the impact of mass tourism is not just found in a few central neighbourhoods, as was the case in the past, but in a growing number of areas. During summer 2014, while the editing process of this book was underway, there were protests in some neighbourhoods of Barcelona against supposedly 'uncivilized' foreign tourists (and other kind of visitors, mainly from North-Western Europe) living in the profit-making 'illegal' apartments mushrooming across the city. The conflict emerged in the Barceloneta neighbourhood, but later spread to other places, including Poble Sec and Sagrada Família. ${ }^{17}$ In some places, after years of economic crisis and housing problems, apart from the inter-group tensions noted along this chapter, a conflict may be emerging between wealthy mobile north-western Europeans (whether or not they are tourists) who have bought or rented bargain apartments in some Barcelona neighbourhoods (sometimes as a second home, part-time residence or business) and the impoverished permanent resident population. However, according to a report quoted by La Vanguardia on 2 September $2014,{ }^{18}$ some members of the former centre-right-wing local government felt that the problem is that many Barcelona residents are not 'cosmopolitan' enough. This strange statement would need further research but, in any case, it is urgent to tackle this and other challenges related to life in super-diverse neighbourhoods seriously, or inter-group tensions could emerge in various and unexpected ways. During the 24 May 2015 municipal elections campaign, these and other issues tackled in this chapter crucially emerged in the political debates. As an outcome of those elections, on 13 June 2015 a new left-wing Barcelona local government was elected with key supports from neighbourhood-based social movements. For the first time in history, the Barcelona Mayor is a woman and the first Vice-Mayor is a non-EU immigrant born in Argentina. In Barcelona, the times they are a-changing.

\footnotetext{
${ }^{17}$ See: http://www.elperiodico.cat/ca/noticias/politica/loposicio-lajuntament-barcelona-suneixles-protestes-contra-lincivisme-3463834 and http://www.btv.cat/btvnoticies/2014/08/30/ manifestacio-turisme-barceloneta-pisos-turistics-veins/

${ }^{18} \mathrm{http} / / /$ www.lavanguardia.com/local/barcelona/20140902/54414202233/pisos-turisticos-inspeccionados-barcelona-ilegales.html
} 
Open Access This chapter is distributed under the terms of the Creative Commons AttributionNoncommercial 2.5 License (http://creativecommons.org/licenses/by-nc/2.5/) which permits any noncommercial use, distribution, and reproduction in any medium, provided the original author(s) and source are credited.

The images or other third party material in this chapter are included in the work's Creative Commons license, unless indicated otherwise in the credit line; if such material is not included in the work's Creative Commons license and the respective action is not permitted by statutory regulation, users will need to obtain permission from the license holder to duplicate, adapt or reproduce the material.

\section{Bibliography}

Ajuntament de Barcelona. (2010). Acta Consell de Barri de la Sagrada Família. http://w3.ben.es/ fitxers/eixample/actacbsagradafamília15dabril2010.891.pdf

Badenas, M. (2006). Fets i gent del Poble Sec i El Paral-lel d'abans. Records i enyorances d'un xicot del barri. Barcelona: Editorial Ajuntament de Barcelona.

Blommaert, J., \& Rampton, B. (2011). Language and super-diversity. Diversities, 13(2), 1-21.

Bruquetas-Callejo, M., Garcés-Mascareñas, B., Morén-Alegret, R., Penninx, R., \& Ruiz-Vieytez, E. (2011). The case of Spain. In G. Zincone, R. Penninx, \& M. Borkert (Eds.), Migration policy-making in Europe (pp. 291-323). Amsterdam: Amsterdam University Press.

CEA. (2009). Informe del projecte Estratègies de participació normalitzada de les persones nouvingudes en espais ciutadans barcelonins: Projecte pilot al barri del Poble Sec. Barcelona: Centre d'Estudis Africans, CEA.

Consorci d'Educació de Barcelona. (2010). L'escolarització a la ciutat de Barcelona. Curs 20092010. Recull estadístic. Abril de 2010, Generalitat de Catalunya, Ajuntament de Barcelona.

Coser, L. (1956). The functions of social conflict. Glencoe: The Free Press.

Creswell, T. (1996). In place/out of place. Geography, ideology, and transgression. London/ Minneapolis: University of Minnesota Press.

Domingo, A., et al. (1995). Condicions de vida de la població d'origen africà i llatinoamericà a la Regió Metropolitana de Barcelona. Barcelona: MMAMB, Diputació de Barcelona, IEMB.

Elias, N., \& Scotson, J. L. (1965/1994). The established and the outsiders. London: Sage.

Fonseca, L., \& Jennifer McGarricle, J. (2012). GEITONIES. Generating interethnic tolerance and neighbourhood integration in European urban spaces (MIGRARE working paper, Vol. 12). Lisbon: Universidade de Lisboa.

Halfacree, K., \& Boyle, P. (1993). The challenge facing migration research: The case for a biographical approach. Progress in Human Geography, 17(3), 333-358.

Izquierdo Cancho, J. A. (2011). Alí y sus amigos: nueva vida pakistaní en Barcelona. Prisma Social: revista de ciencias socialessocials, 6, 63-118.

Joly, D. (Ed.). (1998). Scapegoats and social actors. The exclusion and integration of minorities in Western and Eastern Europe. Houndmills: Macmillan.

Layton-Henry, Z. (1990). Immigrant associations. In Z. Layton-Henry (Ed.), The political rights of migrant workers in Western Europe (pp. 94-112). London: Sage.

Ligüerre i Gil, J. (2007). Evolució del barri fins els nostres dies. http://anticweb.avvsagradafamilia. net/node/133

Marzorati, R. (2011). Conflictos en el espacio público y construcción de la alteridad: una comparación entre barrios en Milán y Barcelona. ACE: Architecture, City and Environment = Arquitectura Ciudad y Entorno, 6(17), 293-316. 
Mayhew, S. (2004). Oxford dictionary of geography. Oxford: Oxford University Press.

Méndez, B., \& Ardévol, E. (2010). Los locutorios: una aproximación etnográfica al uso de las tecnologías de la comunicación entre la población inmigrada del barrio de Sagrada Família de Barcelona. Barcelona: UOC.

Mendoza, C., \& Morén-Alegret, R. (2013). Exploring methods and techniques for the analysis of senses of place and migration. Progress in Human Geography, 37(6), 762-785.

Morén-Alegret, R. (2001). Tuning the channels. Local government policies and 'foreign immigrants' participation in Barcelona. In A. Rogers \& J. Tillie (Eds.), Multicultural policies and modes of citizenship in European cities (pp. 119-145). Aldershot: Ashgate.

Morén-Alegret, R. (2002a). Gobierno local e inmigración extranjera. Aproximación a los casos de Barcelona y Lisboa durante los años 90. Migraciones, 11, 25-91.

Morén-Alegret, R. (2002b). Integration and resistance. The relation of social organizations, global capital, governments and international immigration in Spain and Portugal. Aldershot/ Burlington: Ashgate Publishers.

Morén-Alegret, R. (2005). Joining the human towers? Immigration and social organizations in a small town in Southern Catalonia. Migration, European Journal of International Migration and Ethnic Relations, 43-45, 97-123.

Morén-Alegret, R. (2006). Foreign immigrants' integration in Spain. Canadian Diversity/Diversité Canadienne, 5(1), 80-85.

Morén-Alegret, R. (2007). Bon cop de mà? Món casteller, immigració estrangera i integració a Catalunya. Barcelona: Editorial Mediterrània/Fundació Jaume Bofill/Obra Social Caixa Sabadell.

Morén-Alegret, R. (2008). Ruralphilia and Urbophobia versus Urbophilia and Ruralphobia? Lessons from immigrant integration processes in small towns and rural areas in Spain. Population, Space and Place, 14(6), 537-552.

Morén-Alegret, R., Wladyka, D., \& Mas, A. (2011). Foreign immigration and the 2011 local elections in Barcelona: Channelling diversity? Ethnography, diversity and urban space conference. University of Oxford, Oxford, Sept 2011.

Ojeda Mata, M. (2009). Una primera aproximació a la comunitat jueva dels Encants del Mercat de Sant Antoni de Barcelona, 1882-1939.www.upf.edu/grimse/_pdf/Ojeda_3.pdf

Palou Rubio, S. (2006). La ciudad fingida. Representaciones y memorias de la Barcelona turística. Revista de Turismo y Patrimonio Cultural, 4(1), 13-28.

Pascual, À., Cardelús, J., \& Solana Solana, M. (2000). Recent immigration to Catalonia: Character and responses. In R. King et al. (Eds.), El Dorado or Fortress? (pp. 104-124). London: Macmillan.

Pedone, C. et al. (2010). Migraciones y género en la ciudad. Sobre las diversas formas de pensar y habitar el espacio urbano. In V Congreso Iberoamericano de Estudios de Género. Universidad Nacional de Luján.

Peña, A. (2010, December 8). Entrevista con el agente antirumores: Sergio Toldi: «Incluso yo me equivoco con los inmigrantes». El Periódico de Cataluña, p. 36.

Pla Comunitari del Barri de Sagrada Família. (2008). Diagnòstic comunitari del barri de la Sagrada Família. Idees i propostes principals. Barcelona: Associació de Veïns de Sagrada Família, Coordinadora d'Entitats de Sagrada Família, Pla Comunitari del Barri de Sagrada Família.

Ram, M., Jones, T., Edwards, P., Kiselinchev, A., Muchenje, L., \& Woldesenbet, K. (2013). Engaging with super-diversity: New migrant businesses and the research-policy nexus. International Small Business Journal, 31, 337-356.

RGUB. (2010a). El barri necessita la unió dels serveis municipals. Revista de la Guàrdia Urbana de Barcelona, 37, 30, Octubre.

RGUB. (2010b). La tasca de reeducació és essencial al Poble Sec. Revista de la Guàrdia Urbana de Barcelona, 37, 31, Octubre. 
Ribas, C. (2010). Neix la taula de convivència del Poble Sec per frenar els conflictes socials. El Punt, 9 Feb.

Sanz Parera, M. (1988). El Pla de Barcelona. Constitució i característiques físiques. Sant Cugat del Vallès: Els Llibres de la Frontera.

Sepa Bonaba (Kopesesse), E. (1993). Els negres catalans. Barcelona: Altafulla/Fundació Serveis de Cultura Popular.

Vertovec, S. (2007). Super-diversity and its implications. Ethnic and Racial Studies, 30(6), 1024-1054.

Zegrí, M., Navarro, J. M., \& Aramburu, M. (2006). El encaje de los comercios extranjeros en el tejido comercial de acogida. Análisis de una experiencia de mediación comunitaria en Barcelona. Revista Migraciones, 20, 233-258. 